\title{
DNA oligonucleotides with stereodefined phenylphosphonate and phosphonothioate internucleotide bonds: synthesis and physico-chemical properties
}

\author{
Milena Sobczak, ${ }^{a}$ Tommy Johansson, ${ }^{\text {b }}$ Marek Bulkowski, ${ }^{a}$ Marek Sochacki, ${ }^{\text {c }}$ Gaston \\ Lavén, ${ }^{\mathrm{b}}$ Barbara Mikolaczyk, ${ }^{\mathrm{a}}$ Jacek Stawinski, ${ }^{\mathrm{b}, \mathrm{d}, *}$ and Barbara Nawrot ${ }^{\mathrm{a}, *}$ \\ ${ }^{a}$ Department of Bioorganic Chemistry and ${ }^{c}$ Laboratory for Analysis of Organic Compounds and \\ Polymers of Centre of Molecular and Macromolecular Studies, Polish Academy of Sciences, \\ Sienkiewicza 112, 90-363 Lodz, Poland \\ ${ }^{b}$ Department of Organic Chemistry, Arrhenius Laboratory, Stockholm University, \\ S-106 91 Stockholm, Sweden \\ ${ }^{d}$ Institute of Bioorganic Chemistry, Polish Academy of Sciences, Noskowskiego 12/14, \\ 61-704 Poznan, Poland \\ E-mail: bnawrot@bio.cbmm.lodz.pl; js@organ.su.se
}

Dedicated to Prof. Pawel Kafarski to honor the achievements within his career

\begin{abstract}
Separate diastereomers of suitably protected dithymidine (3',5')-phenylphosphonates and dithymidine (3',5')-phenylphosphonothioates were obtained via a palladium(0) catalysed stereospecific cross-coupling reaction between separate diastereomers of the corresponding dinucleoside $\mathrm{H}$-phosphonates and dinucleoside H-phosphonothioates with iodobenzene. These compounds were converted into the corresponding phosphoramidite building blocks and used for incorporation of P-stereodefined dithymidine phenylphosphonate and phenylphosphonothioate units TxT into DNA oligonucleotide chain. Dodecathymidylates with centrally positioned one $\left(\mathrm{T}_{9} \mathrm{TxTT}_{9}\right)$ or two modified units $\left(\mathrm{T}_{8} \mathrm{TxTTxTT}_{8}\right)$ exhibited different affinity towards complementary DNA $\left(\mathrm{dA}_{20}\right)$ or RNA $\left(\mathrm{A}_{20}\right)$ strands depending on stereochemistry at the phosphorus center, as determined by UV melting temperature studies. Oligonucleotides containing the $R_{\mathrm{P}}$-phenylphosphonate or $R_{\mathrm{P}}$-phenylphosphonothioate internucleotide linkages exhibited higher binding affinity to the complementary strands than their $S_{\mathrm{P}}$-counterparts, but slightly lower than the non-modified reference $\mathrm{T}_{20}$. All phenylphosphonothioate-modified oligonucleotides formed less stable than their oxo-counterparts duplexes. As expected, the cleavage of the oligonucleotides investigated with 3'- and 5'-exonucleases was stalled at the modification site, independently of P-chirality at the modification site.
\end{abstract}

Keywords: Oligonucleotide analogues, phenylphosphonates, phenylphosphonothioates, Pchirality, Tm, Nuclease resistance 


\section{Introduction}

Analogues of natural oligonucleotides bearing a $\mathrm{P}-\mathrm{C}$ bond at the non-bridging position of an internucleotide bond have been early recognised as promising candidates for nucleic acids-based therapeutics, especially for an antisense therapy, ${ }^{1,2}$ due to the enhanced resistance towards nucleases. The appealing feature of $\mathrm{C}$-phosphonate derivatives as antisense or antigene agents is also lack of a negative charge at the phosphorus centre that may facilitate a cellular uptake of these compounds via increasing passive transport through cellular membranes. ${ }^{3}$ By varying number of the P-C bonds present in an oligonucleotide, a general lipophilicity can be modulated, and due to chirality of the phosphorus center of C-phosphonate diesters, stability of the formed complexes can be adjusted by a proper choice of the P-stereochemistry. ${ }^{4}$

In contrast to oligonucleotide methylphosphonates, that have been the focus of oligonucleotide analogues research since the early days of an antisense therapy, ${ }^{1}$ the corresponding phenylphosphonate derivatives received much less attention.

Preliminary studies on the binding properties of phenylphosphonate $\left(R_{\mathrm{P}} / S_{\mathrm{P}}\right)$-modified oligonucleotides showed $^{5,6}$ that despite of steric bulkiness of a phenylphosphonate group, its introduction caused only small destabilization to a DNA-DNA type of duplexes, comparable to those observed for methylphosphonate and phosphorothioate modifications $(\Delta \mathrm{Tm}-0.3$ to -1.0 ${ }^{\circ} \mathrm{C}$ ). An interesting observation was the fact that for complexes with RNA targets, no destabilization could be detected at all, and for some oligonucleotides bearing multiple phenylphosphonate modifications, an increase in Tm was observed. ${ }^{6}$

As part of our interest in P-chiral oligonucleotide analogues we recently investigated hybridization properties of isomeric pyridylphosphonates-containing oligonucleotides ${ }^{7}$ with single- and double-stranded DNA targets. We found that stereochemistry at the phosphorus center, as well as a position of the nitrogen atom in the pyridylphosphonate moiety, played a significant role in stability of the complexes formed.

As a continuation of these studies, in this paper we describe synthesis of separate diastereomers of dinucleoside phenylphosphonates and phenylphosphonothioates, their incorporation at preselected positions of model oligodeoxyribonucleotides, and determination of hybridization ability of the modified oligonucleotides towards complementary DNA and RNA strands. These studies, together with our previous findings on pyridylphosphonates-containing oligonucleotides should shed some light on the contribution of hydrophobic and polar factors in stabilization of double-stranded DNA complexes, and thus be helpful in designing new antisense/antigene agents. 


\section{Results and Discussion}

\section{Synthesis of P-stereodefined dithymidine phenylphosphonates and phenylphosphono- thioates}

The first synthesis of nucleoside phenylphosphonates was done by Todd el al. ${ }^{8}$ who for the purpose of investigation of biological properties of this AMP analogue, prepared adenosine 5'phenylphosphonate monoester via the reaction of phenylphosphonodichloridate with adenosine. This method was not particularly general and thus the first synthesis of dinucleoside phenylphosphonates ${ }^{9}$ and their incorporation into oligonucleotides was achieved via a stepwise condensation of nucleosides with phenylphosphonoditriazolide, followed by condensation in the presence of benzenesulfonyltetrazole. ${ }^{10}$ The method was further modified and significantly improved by using 6-nitrobenzotriazol-1-yl-oxy-tris (dimethylamino)phosphonium hexafluorophosphate (NBOP) as a condensing agent and the corresponding nucleoside 3'phenylphosphonates as nucleotidic substrates. ${ }^{11}$ Since in both methods achiral phosphonylating agents were used, the dinucleoside phenylphosphonates were produced as a mixture of diastereomers.

Another synthetic approach based on tervalent phosphorus compounds, namely nucleoside phenylphosphonamidite derivatives, ${ }^{5,6}$ permitted the introduction of phenylphosphonate and phenylphosphonothioate $^{6}$ modifications into oligonucleotides. Similarly to the previous approaches based on $\mathrm{P}(\mathrm{V})$ intermediates, this method also produced mixtures of phenylphosphonate diastereomers that in some instances could be resolved into stereochemically pure species. $^{5,6}$

To facilitate synthesis of stereodefined oligonucleotide analogues and other biologically important phosphorus compounds containing a C-P bond, we developed a stereospecific synthesis of dinucleoside phenylphosphonates and phenylphosphonothioates via a palladium cross-coupling reaction. $^{12,13}$ This chemistry was applied to the synthesis of dinucleoside phenylphosphonate and phenylphosphonothioate building blocks as shown in Scheme 1.

As starting materials we used suitably protected diastereomerically pure dinucleoside $\mathrm{H}$ phosphonates 1 and H-phosphonothioates 2 synthesised as described previously. ${ }^{14}$ These were subjected to a cross-coupling reaction with iodobenzene in THF, catalyzed by $\operatorname{Pd}(0)$. For the synthesis of phenylphosphonates $3, \mathrm{Pd}(\mathrm{OAc})_{2}$ was used as a precatalyst together with 1,1bis(diphenylphosphino)ferrocene (dppf) as a supporting ligand, ${ }^{12}$ while for the synthesis of phenylphosphonothioate derivatives 4, $\mathrm{Pd}\left(\mathrm{PPh}_{3}\right)_{4}$ was employed. ${ }^{15}$ Both reactions were completely stereospecific and occurred most likely with retention of configuration at the phosphorus centre. The 3'-O-TBDMS protecting groups in phosphonate $\mathbf{3}$ and phosphonothioate 4 were then removed using a solution of TBAF in tetrahydrofuran. In this way, two isomeric dinucleoside phenylphosphonates of type $\mathbf{5}$ and two isomeric dinucleoside phenylphosphonothioates of type 6, were prepared. 


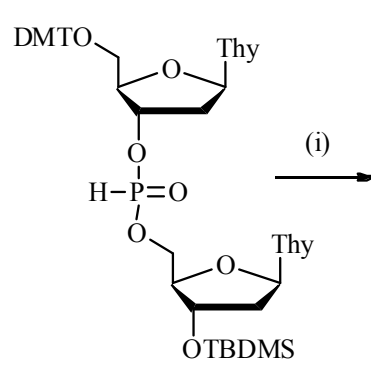

1

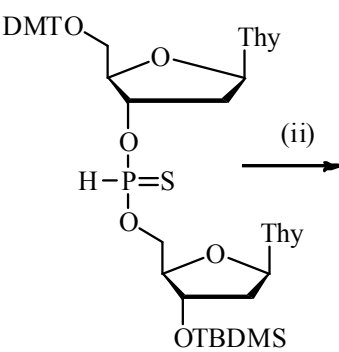

2

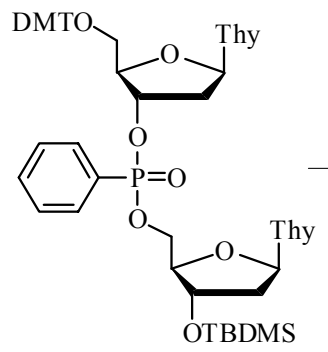

3

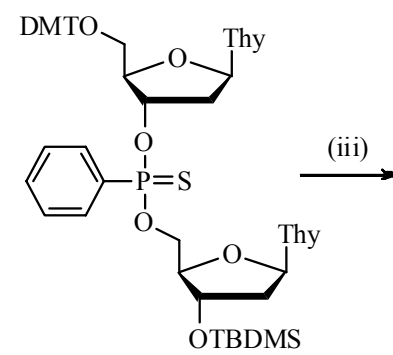

4

(iii)
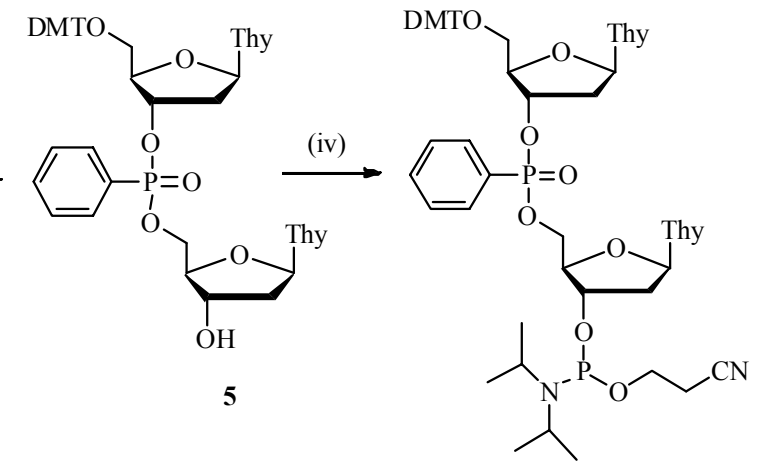

7
(i) $\mathrm{Pd}(\mathrm{OAc})_{2}, \mathrm{dppf}, \mathrm{PhI}, \mathrm{Et}_{3} \mathrm{~N}, \mathrm{THF}$
(ii) $\mathrm{Pd}\left(\mathrm{PPh}_{3}\right)_{4}, \mathrm{PhI}, \mathrm{Et}_{3} \mathrm{~N}, \mathrm{THF}$
(iii) $1 \mathrm{M}$ TBAF, THF
(iv) $\left((\text { isoPr })_{2} \mathrm{~N}\right)_{2} \mathrm{P}-\mathrm{OCE}, \mathrm{CH}_{2} \mathrm{Cl}_{2}$, EtS-tetrazole

$\mathrm{DMT}=4$, 4-dimethoxytrityl
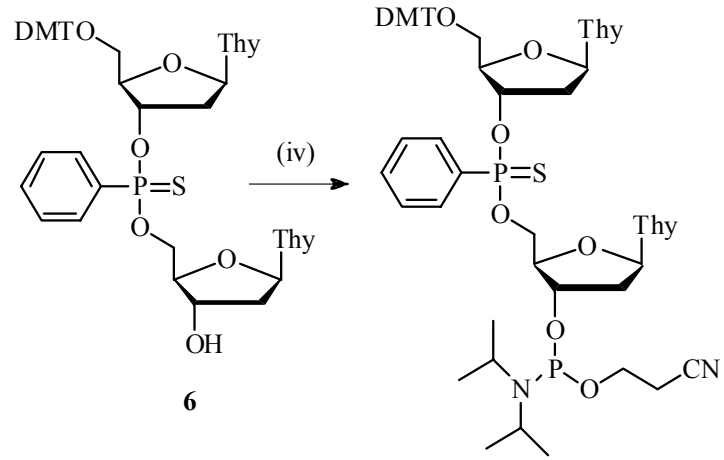

6

TBDMS $=$ tert-butyldimethylsilyl

Thy $=$ thymin-1-yl

\section{Scheme 1}

The absolute configurations at the phosphorus center $\left(R_{\mathrm{P}} / S_{\mathrm{P}}\right)$ of dinucleoside phenylphosphonates 3 and phenylphosphonothioates $\mathbf{4}$ were tentatively assigned on the basis of known stereochemistry of the parent diastereomers of dinucleoside H-phosphonate derivatives $\mathbf{1}^{16}$ and $\mathbf{2}^{17}$ used for the reaction, and the assumption that the conversions of $\mathbf{1}$ into phenylphosphonates $\mathbf{3}$ and $\mathbf{2}$ into phenylphosphonothioates $\mathbf{4}$, occurred with retention of configuration. $^{12,18}$

\section{Synthesis of phosphoramidite building blocks}

The obtained P-stereodefined dithymidyl-3',5'-phenylphosphonates 5 and dithymidyl-3',5'phenylphosphonothioates 6 were used as substrates for the preparation of the corresponding phosphoramidite units $\mathbf{7}$ and $\mathbf{8}$, respectively (Scheme 1). The method of choice was the use of 2cyanoethyl $N, N, N^{\prime}, N^{\prime}$-tetraisopropyl-phosphordiamidite as a phosphitylation reagent in the presence of $S$-ethyltetrazole in methylene chloride. ${ }^{19}$ The reaction was carried out at room temperature under argon and its progress was monitored by TLC analysis. When the formation of the desired products was complete (usually no longer than 1 hour), the reaction mixture was 
chromatographed on a silica gel column using hexane-ethyl acetate $(1: 1, \mathrm{v} / \mathrm{v})$ with $1 \%$ of triethylamine and increased amount (up to 5\%) of methanol. The corresponding phosphoramidites $\mathbf{7} \boldsymbol{R}_{\mathbf{P}}$ and $\mathbf{7} \boldsymbol{S}_{\mathbf{P}}$ as well as $\mathbf{8} \boldsymbol{R}_{\mathbf{P}}$ and $\mathbf{8} S_{\mathbf{P}}$ were isolated with reasonable yields (68$89 \%$ ), and their structures were confirmed by ${ }^{31} \mathrm{P}$ NMR. Phosphoramidites 7 and $\mathbf{8}$ were rather stable and could be stored as foams for a prolonged time (months) under argon at $-20^{\circ} \mathrm{C}$.

\section{Synthesis of oligonucleotides}

3'-O-Phosphoramidite building blocks 7 and $\mathbf{8}$ were used for incorporation of the stereodefined phenylphosphonate or phenyl phosphonothioate moieties, respectively, into oligodeoxyribonucleotide (ODN) chain by automated solid phase synthesis. ${ }^{20}$ Two types of oligothymidylates: $\mathrm{T}_{9} \mathrm{TxTT}_{9}$ and $\mathrm{T}_{8} \mathrm{TxTTxTT}_{8}$ (carrying one or two modified internucleotide linkages, where $\mathrm{x}$ represents the corresponding phenyl-phosphonate or phosphonothioate linkage), were designed for these studies. The list of the eight modified oligonucleotides ODN2ODN9 used in these studies is shown in Table 1. The synthesis of oligomers was performed on Gene Word DNA/RNA Synthesizer in $0.2 \mathrm{mmol}$ scale using succinyl-linked LCA-CPG solid support. The commercially available phosphoramidite monomer of thymidine (Glen Research) as well as phosphoramidites $7 R_{\mathbf{P}}, \mathbf{7} S_{\mathbf{P}}, \mathbf{8} R_{\mathbf{P}}$ and $\mathbf{8} S_{\mathbf{P}}$ were used for the synthesis. The synthesis was performed according to the standard phosphoramidite methodology except for the extended coupling time (up to $600 \mathrm{~s}$ ) that was used for incorporation of the modified units. The coupling efficiency for all four modified units was moderate (in the range of $60 \%$, as determined by DMT-ion assay). To cleave the oligomers from the solid support and to remove base-labile protecting groups, a standard ammonia treatment (28\% ammonium hydroxide, $55{ }^{\circ} \mathrm{C}, 4 \mathrm{~h}$ ) was used, followed by a two-step purification-deprotection procedure. ${ }^{21}$ The structure and purity of fully deprotected modified oligonucleotides ODN2-ODN9 were confirmed by MALDI-TOF mass spectrometry (data in Table 1), reverse phase HPLC analysis, and polyacrylamide gel electrophoresis (PAGE) (data not shown).

Table 1. The sequences of model oligonucleotides used in these studies and their MALDI-TOF mass spectrometry data

\begin{tabular}{cccccc}
\hline $\begin{array}{c}\text { Oligo- } \\
\text { nucleotide }\end{array}$ & $\begin{array}{c}\text { Sequence } \\
\left(5^{\prime} \rightarrow 3^{\prime}\right)\end{array}$ & $\mathrm{x}$ & $\begin{array}{c}\text { MALDI-TOF MS } \\
m / z\end{array}$ & $\mathrm{M} . \mathrm{W}$. & $\begin{array}{c}\text { Yield } \\
(\mathrm{OD})\end{array}$ \\
\hline ODN 1 & $\mathrm{T}_{20}$ & - & 6018 & 6022 & 22 \\
ODN 2 & & $R \mathrm{p} \mathrm{PhPO}$ & 6079 & 6082 & 10 \\
ODN 3 & \multirow{2}{*}{$\mathrm{T}_{9} \mathrm{TxT} \mathrm{T}_{9}$} & Sp PhPO & 6077 & 6082 & 13 \\
ODN 4 & & $R \mathrm{p} \mathrm{PhPS}$ & 6093 & 6098 & 14 \\
ODN 5 & & $S \mathrm{p} \mathrm{PhPS}$ & 6095 & 6098 & 19 \\
ODN 6 & & $R \mathrm{p} \mathrm{PhPO}$ & 6147 & 6142 & 11 \\
ODN 7 & \multirow{2}{*}{$\mathrm{T}_{8}$ TxT TxT T } & Sp PhPO & 6144 & 6142 & 12 \\
ODN 8 & & $R p$ PhPS & 6156 & 6158 & 11 \\
ODN 9 & & $S p$ PhPS & 6154 & 6158 & 15 \\
\hline
\end{tabular}




\section{Comparison of chromatographic mobility of oligothymidylates containing phenyl- phosphonate or phosphonothioate linkages}

We analyzed chromatographic mobilities of oligonucleotides ODN2 - ODN5 on the reverse phase column HPLC to determine their relative hydrophobicity using triethylamine bicarbonate $\mathrm{pH}$ 7.5/acetonitrile buffer system. The HPLC profiles of the screened oligonucleotides are shown at Figure 1.

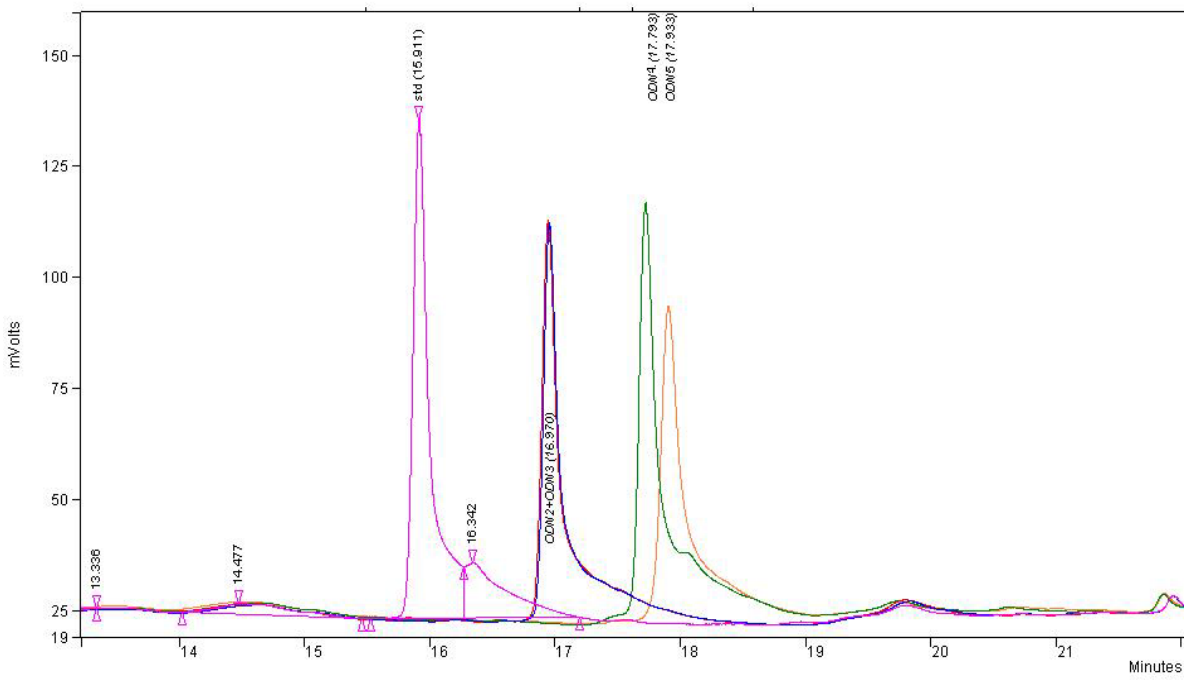

Figure 1. Comparison of RP-HPLC profiles of oligonucleotides containing phenylphosphonate and phosphonothioate linkages with $R_{\mathrm{P}}$ and $S_{\mathrm{P}}$ configuration, and the reference $\mathrm{T}_{20}$. The retention times (Rt) were as follow: $\mathrm{T}_{20}-15.94 \mathrm{~min}$; ODN2 - $16.94 \mathrm{~min}$; ODN3 - $16.97 \mathrm{~min}$; ODN4 $17.15 \mathrm{~min}$; ODN5 - $17.92 \mathrm{~min}$ (ODN numbering according to Table 1 . The reverse phase HPLC analysis was performed on a Gilson apparatus with ThermoQuest Hypersil ODS $5 \mathrm{~m}$ column (250x4.6 mm) using 0.1 M triethylamine bicarbonate $\mathrm{pH} 7.5$ /acetonitrile buffer system.

The presented data indicate that phenylphosphonate oligonucleotides ODN2 and ODN3 are more hydrophobic than the parent $\mathrm{T}_{20}$ oligonucleotide (Rt $15.94 \mathrm{~min}$ ), and eluted from the RP column at Rt 16.94 and 16.97 min, respectively. No significant differences were observed for these two oligonucleotides in terms of their P-chirality. In contrary, both phenylphosphonothioate-modified oligonucleotides DNA4 and DNA5 elute with longer Rt

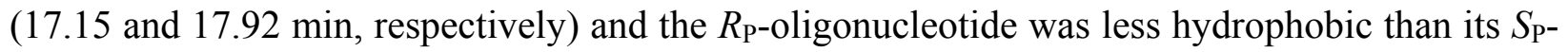
counterpart.

While increased hydrophobicity of these novel DNA analogues may be favourable in respect to their cellular uptake, this feature will limit their solubility in aqueous solutions. 


\section{Structural analysis of duplexes containing phenylphosphonate and phenylphosphono- thioate bonds by circular dichroism}

The influence of stereodefined phenylphosphonate and phenylphosphonothioate linkages on geometry of the duplexes formed with unmodified counterparts was investigated by circular dichroism spectroscopy (CD). The CD spectra of four $\mathrm{DNA} / \mathrm{dA}_{20}$ duplexes and their parent reference $\mathrm{T}_{20} / \mathrm{dA}_{20}$ complex are shown at Figure $2 \mathrm{~A}$. From this set of spectra it is clear that complementary duplexes of $\mathrm{dA}_{20}$ with modified strands ODN6 (red line), ODN7 (black line), ODN8 (dark blue line) or ODN9 (green line) adopt similar geometry to their unmodified counterpart $\mathrm{T}_{20} / \mathrm{dA}_{20}$ (light blue line). Only a small differences were observed in the magnitude of ellipticity for the duplex ODN9/ $\mathrm{dA}_{20}$. This feature probably originates from the presence of phosphonothioate residues of the $S_{\mathrm{P}}$ configuration. As it was already proven (see further in the text) this modification causes the most significant distortion of a duplex structure.

A)

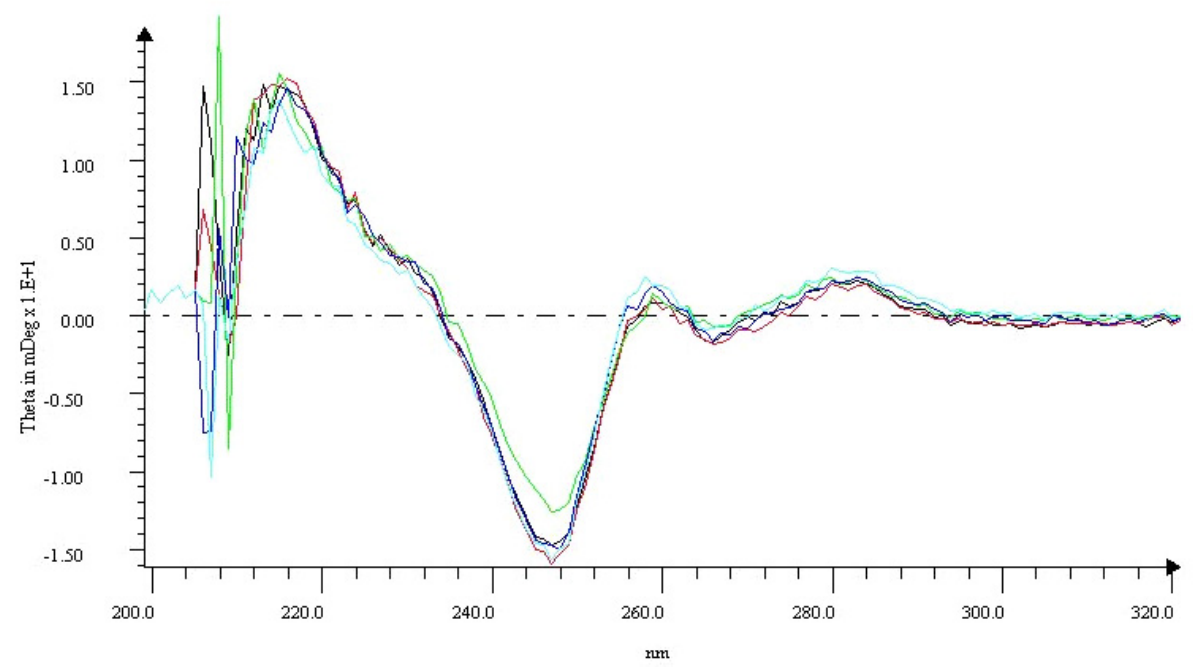

B)

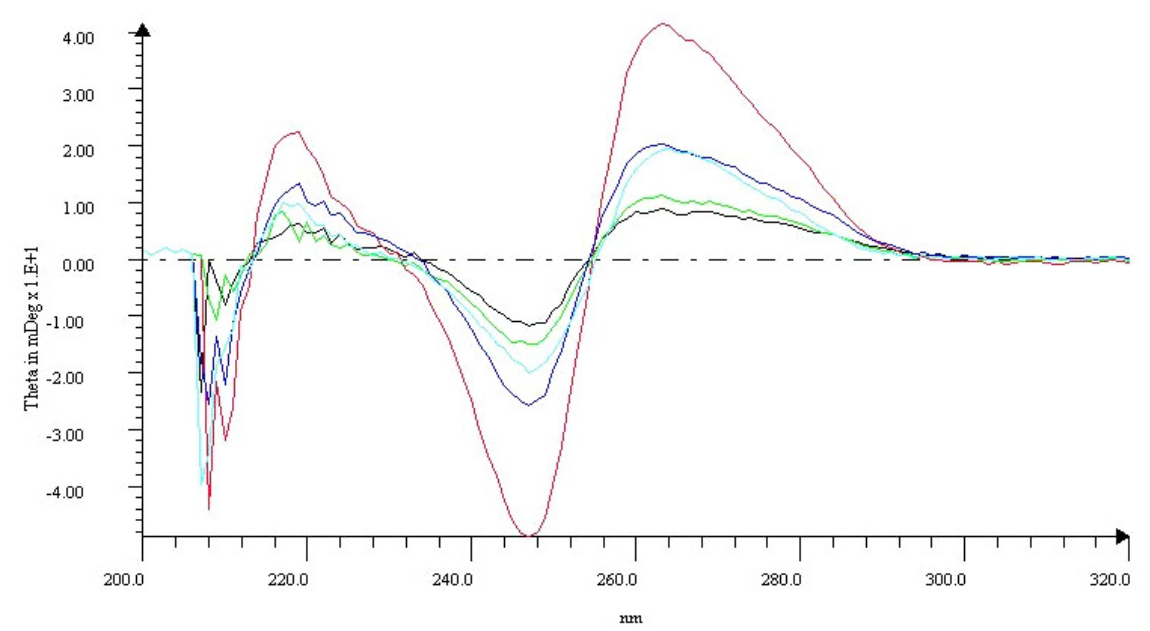

Figure 2. CD spectra of duplexes of ODN6 - ODN9 oligonucleotides with complementary dA 20 (A) and $\mathrm{A}_{20}$ (B) strands. Duplexes with ODN6 - red line; ODN7 - black line; ODN8 - dark blue line; ODN9 - green line; reference duplexes - light blue line. 
The CD spectra of four complexes with complementary oligoribonucleotide target, DNA/A $A_{20}$, are shown at Figure $2 \mathrm{~B}$. In general, all these $\mathrm{CD}$ spectra have a shape similar to that of the $\mathrm{CD}$ spectrum of their parent reference $\mathrm{T}_{20} / \mathrm{A}_{20}$, exhibiting a maximum of the Cotton Effect at $247 \mathrm{~nm}$ (negative band) and 218 and $263 \mathrm{~nm}$ (positive bands). Interestingly, the intensities of the Cotton effects differ significantly depending on the stereochemistry and the structure of the phosphorus center. Duplexes containing a modification with the $R_{\mathrm{P}}$ configuration exhibited bigger amplitude of ellipticity than their $S_{\mathrm{P}}$-counterparts, and the phenylphosphonate modification in ODN 6/A $/ \mathrm{A}_{20}$ duplex had more pronounced effect than the phenylphosphonothioate modification in ODN 8/ $\mathrm{A}_{20}$ duplex. The latter one, in fact, exhibited ellipticity amplitude similar to non-modified parent duplex. In contrast, both duplexes containing the $S_{\mathrm{P}}$-chiral center showed smaller ellipticity amplitudes than the reference duplex. These results suggest that duplexes of the $S_{\mathrm{P}}$-modified oligonucleotides with RNA are more structurally disordered. This observation can be due to some duplex deformations, as the CD spectra around $270 \mathrm{~nm}$ are highly sensitive to the changes of angle between neighboring bases. This is especially important for RNA, where the second and third nearest neighbors contribute together more to intensity of the CD bands than the nearest neighbors in DNA. ${ }^{22}$

\section{Hybridization properties of oligonucleotides ODN2-ODN9}

Binding affinity of oligonucleotides ODN2-ODN9 to the complementary oligonucleotides $\mathrm{dA}_{20}$ and $\mathrm{A}_{20}$ was determined by the UV melting temperature measurements at $\mathrm{pH}$ 7.5. As is shown in Table 2, stability of the corresponding duplexes strongly depends on the sense of chirality at the phosphorus atom of the phenlyphosphonate and phenylphosphonothioate units. The DNA/DNA and DNA/RNA type of duplexes with $R_{\mathrm{P}}$-phenylphosphonate and $R_{\mathrm{P}}$-phenylphosphonothioate units (ODN2, ODN4, ODN6 and ODN8) are more thermodynamically stable than their $S_{\mathrm{P}^{-}}$ counterparts (oligonucleotides ODN3, ODN5, ODN7 and ODN9) but still less stable than the parent, non-modified reference complexes $\mathrm{T}_{20} / \mathrm{dA}_{20}$ and $\mathrm{T}_{20} / \mathrm{A}_{20}$. The differences in $\mathrm{Tm}$ values $(\Delta \mathrm{Tm})$ per each introduced $R_{\mathrm{P}}$ or $S_{\mathrm{P}}$-phenylphosphonate bond are ca. 1.0 or $3.0^{\circ} \mathrm{C}$, respectively,

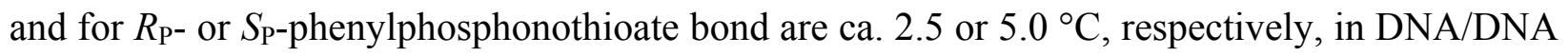
duplexes. The corresponding $\Delta \mathrm{Tm}$ values for DNA/RNA duplexes are ca. 2.0 or $3.5^{\circ} \mathrm{C}$ per each

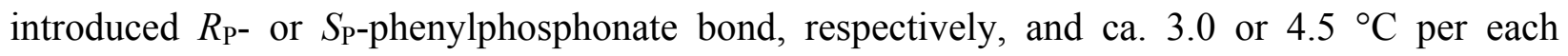
introduced $R_{\mathrm{P}}$ - or $S_{\mathrm{P}}$-phenylphosphonothioate bond, respectively with the estimated measurement error $\pm 0.5^{\circ} \mathrm{C}$. A possible reason why the $S_{\mathrm{P}}$-phenylphosphonate units destabilize the structure of the respective DNA/DNA and DNA/RNA duplexes to a higher extent than their $R_{\mathrm{P}}$-counterparts can be the sterically unfavourable inward positioning of the phenyl ring in the formed duplexes. Similarly, duplexes bearing $R_{\mathrm{P}}$-methylphosphonate linkages usually exhibit higher thermal stability than their Sp-counterparts, but still they are not as stable as their non-modified references. ${ }^{23}$ It was postulated that the increased stability can be due to a more favorable solvation effect for $R_{\mathrm{P}}$ methylphosphonate derivatives. ${ }^{24}$ Molecular dynamics simulations performed for methylphosphonate oligonucleotides demonstrated that neutralization of charges in the DNA chain due to the presence of the P-methyl groups affects the electrostatic 
environment around the minor groove of the helix - a region in which structural water molecules and metal cations are the localized. ${ }^{25}$ We also demonstrate that methylphosphoramidate oligonucleotides of $R_{\mathrm{P}}$ configuration ${ }^{26}$ bind stronger to their complementary strands than their $S_{\mathrm{P}^{-}}$ counterparts. ${ }^{27}$ In other studies we have shown that modified oligonucleotides containing $R_{\mathrm{P}^{-}}$ pyridylphosphonate internucleotide bonds bind stronger to complementary DNA sequences than their $S_{\mathrm{P}}$-counterparts and their complexes are usually as stable as those derived from the corresponding unmodified oligonucleotides. ${ }^{7} \quad$ For $^{2}$ pyridylphosphonates-modified oligonucleotides apparently, apart from reducing electrostatic repulsions, the presence of the pyridine ring may provide an alternative mode of hydration for the system and can be the additional source of stabilizing stacking interactions with nucleobases.

Importantly, the introduction of a sulfur atom into the internucleotide phenylphosphonate bond caused destabilization of the corresponding duplexes of ca. $1.0-2.0^{\circ} \mathrm{C}$ per modification. This can be due to larger van der Waals radius of sulfur vs. oxygen (possible steric hindrance) and also the weaker H-bonding ability of sulfur relative to oxygen.

Table 2. Binding affinity of homothymidylates ODN2 - ODN9 towards $\mathrm{dA}_{20}$ and $\mathrm{A}_{20}$ single stranded DNA and RNA templates. All melting temperatures (Tm ) were determined at $\mathrm{pH} 7.5$

\begin{tabular}{|c|c|c|c|c|}
\hline \multirow[t]{2}{*}{ Oligo } & \multirow[t]{2}{*}{ Sequence $\left(5^{\prime} \rightarrow 3^{\prime}\right)$} & \multirow[t]{2}{*}{$\mathrm{X}$} & \multicolumn{2}{|c|}{$\operatorname{Tm}(\Delta \operatorname{Tm})\left[{ }^{\circ} \mathrm{C}\right]$} \\
\hline & & & Template $\mathrm{dA}_{20}$ & Template $\mathrm{A}_{20}$ \\
\hline 1 & $\mathrm{~T}_{20}$ & - & 54.8 & 46,1 \\
\hline 2 & & $R p \mathrm{PhPO}$ & $53.9(-0.9)$ & $44.2(-1.9)$ \\
\hline 3 & $\mathrm{~T}_{9} \mathrm{TxT} \mathrm{T}_{9}$ & Sp PhPO & $51.2(-3.6)$ & $42.0(-4.1)$ \\
\hline 4 & & $R \mathrm{p}$ PhPS & $52.3(-2.5)$ & $43.9(-2.2)$ \\
\hline 5 & & Sp PhPS & $50.2(-4.6)$ & $41.6(-4.5)$ \\
\hline 6 & & $R p \mathrm{PhPO}$ & $52.2(-2.6)$ & $41.4(-4.7)$ \\
\hline 7 & $\mathrm{~T}_{8} \mathrm{TxT} \mathrm{TxT} \mathrm{T}_{8}$ & Sp PhPO & $48.2(-6.6)$ & $38.6(-7.5)$ \\
\hline 8 & & $R p \mathrm{PhPS}$ & $49.3(-5.5)$ & $40.2(-5.9)$ \\
\hline 9 & & Sp PhPS & $44.2(-10.6)$ & $37.1(-9.0)$ \\
\hline
\end{tabular}

\section{Stability against 3'- and 5'-exonucleases analysed by MALDI-TOF MS}

All screened oligonucleotides ODN2- ODN5 were subjected to the exonucleolytic cleavage with 3'- and 5'-exonucleases. The oligonucleotides were incubated either with snake venom phosphodiesterase (PDE I), which is a 3'-exonuclease, or with calf spleen phosphodiesterase (PDE II), which is a 5'-exonuclease. As expected, the phenylphosphonate oligonucleotides investigated were digested along the chain up to the modification site, and products containing the ultimate 3'- or 5'-phenylphosphonate or phosphonothioate TxT units, were accumulated. The reaction mixtures after given incubation were analyzed by MALDI-TOF mass spectrometry and the products were identified by assigning to the molecular peaks present. For example, the digestion of oligonucleotide ODN4 (oligothymidylate containing phenylphosphonothioate linkage of the $R$ p configuration) with the 3 '-exonuclease PDE I resulted in the appearance of a 
set of peaks ranging from $\mathrm{T}_{9} \mathrm{TxTT}_{9}$ (negative ion $\mathrm{m} / \mathrm{z}$ 6093) to $\mathrm{T}_{9} \mathrm{TxT}(\mathrm{m} / \mathrm{z} 3359)$ (Figure 3 ). The other modified oligonucleotides gave similar sets of MALDI-TOF MS signals when digested by both investigated enzymes (results not shown). These results confirmed that cleavage of the oligonucleotides with 3'- and 5'-exonucleases stalled at the modification site, independently of chirality at the phosphorus centre.

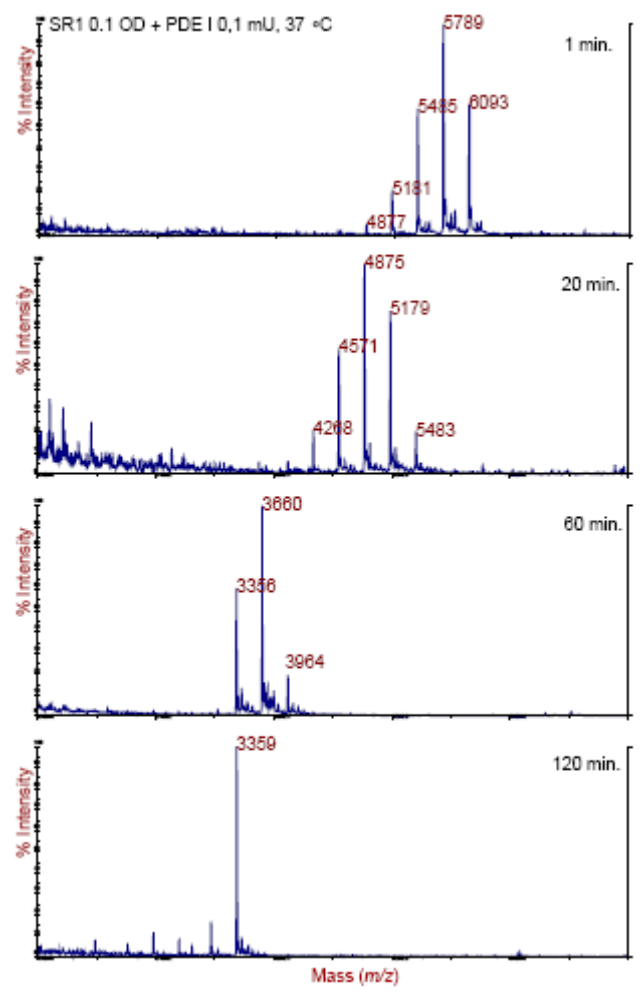

Figure 3. Digestion of ODN4 with snake venom phosphodiesterase (PDE I, 3'-exonuclease). MALDI-TOF spectra were collected after 1, 20,60 and $120 \mathrm{~min}$ of cleavage reaction. The final product of the digestion accumulating in the reaction mixture corresponded to $\mathrm{m} / \mathrm{z} 3359$.

\section{Conclusions}

All the investigated oligodeoxynucleotides bearing phenylphosphonate or phenylphosphonothioate modifications at the internucleotide bonds formed stable complexes with complementary $\mathrm{dA}_{20}$ and $\mathrm{A}_{20}$ oligonucleotides and showed cooperative melting transitions at $\mathrm{pH}$ 7.5. The duplexes were less stable than their unmodified counterparts, showing differences in $\Delta \mathrm{Tm}$ between investigated pairs of the following type: DNA/DNA vs. DNA/RNA complexes, phenylphosphonate vs. phenylphosphonothioate modifications, and those having $R_{\mathrm{P}}$ vs. $S_{\mathrm{P}}$

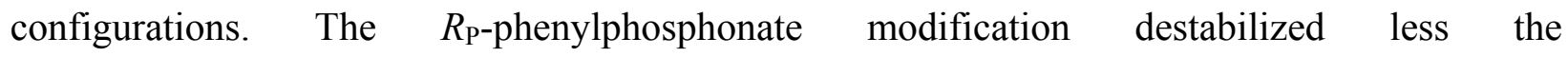
oligodeoxynucleotide duplexes ( $\Delta \mathrm{Tm}-0.9$ to $-1.3 \mathrm{deg}$ per modification) than those with 
oligoribonucleotide target sequence ( $\Delta \mathrm{Tm}-1.9$ to $-2.3 \mathrm{deg}$ ). These differences for $S_{\mathrm{P}-}$ phenylphosphonate modifications were for the DNA/DNA complexes ca -3.3 to $-3.6 \mathrm{deg}$, and for the DNA/RNA complexes, -3.8 to $-4.1 \mathrm{deg}$. For phenylphosphonothioate modifications, the

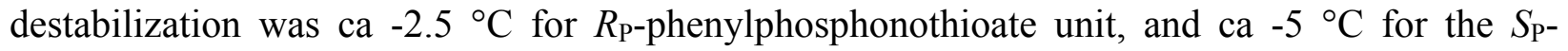
counterparts, for both types of the investigated complexes.

The observed destabilizations of the corresponding duplexes, due to the presence of phenylphosphonate and phenylphosphonothioate modifications, are higher than those reported by Engles et $a l .{ }^{6}$ This could be due to several factors, such as using mixtures of the diastereomers, oligonucleotides with hetero sequences and different positions of the modifications in the oligonucleotidic chain.

By comparing the results from this study to those of the pyridylphosphonate modifications ${ }^{7}$ one can speculate that replacement of a carbon by a nitrogen atom in the aromatic ring confers some stabilization to the complexes formed, especially those with deoxyribonucleotide complementary sequences.

To sum up, since destabilization by phenylphosphonate/phenylphosphonothioate modifications is sensitive to configuration at the phosphorus center and the presence or absence of the phosphorus-bound sulfur, these structural motifs potentially can be used, alone or in combination with other modifications, for fine tuning thermal stability DNA-DNA or DNA-RNA hybrids for the purpose of antisense therapy or other medicinal applications.

\section{Experimental Section}

General. All reagents were of analytical grade obtained from commercial suppliers, and were used without further purification. Starting materials $\mathbf{1}$ and $\mathbf{2}$ were prepared analogously to the published procedures. ${ }^{14}$ Anhydrous THF was freshly distilled from sodium/benzophenone, under argon atmosphere. Column chromatography was performed on silica gel (Grace Davison, Davsil, 0.035-0.070 $\mathrm{mm}$ ). After chromatography fractions containing product were pooled, evaporated to dryness and dried under vacuum for 12 hours. NMR spectra were recorded on Varian Gemini $400 \mathrm{MHz}$ or Bruker Avance II $500 \mathrm{MHz}$ spectrometers. Chemical shifts are reported in ppm relative to solvent peaks $\left({ }^{1} \mathrm{H},{ }^{13} \mathrm{C}\right)$ and $\mathrm{H}_{3} \mathrm{PO}_{4}\left({ }^{31} \mathrm{P}\right.$; external standard $)$. Assignments of the NMR signals based on 2D correlation experiments (COSY, HSQC, HMBC). Signals in the NMR spectra originating from 4,4'-dimethoxytrityl, phenyl, nucleoside-3'-yl and nucleoside-5'-yl moieties are indicated with "DMT", "Ph", "a" and "b" subscripts, respectively. High resolution mass spectra (HRMS) were recorded in positive mode on Bruker microTOF ESI mass spectrometer.

5'-O-(4,4'-Dimethoxytrityl)thymidin-3'-yl 3'-O-tert-butylsilylthymidin-5'-yl phenylphosphonates (3- $\boldsymbol{R}_{\mathbf{P}}$ and $\left.\mathbf{3}-\boldsymbol{S}_{\mathbf{P}}\right)$. Solution of PhI1M TBD (14 $\left.\mathrm{mg}, 0.06 \mathrm{mmol}\right), 1,1$ bis(diphenylphosphino)ferrocene (dppf; $33 \mathrm{mg}, 0.06 \mathrm{mmol}$ ) and $\mathrm{H}_{2} \mathrm{O}(2 \mu \mathrm{L}, 2 \mathrm{mg}, 0.1 \mathrm{mmol})$ in 
THF $(10 \mathrm{~mL})$ was stirred for 15 minutes, at $60{ }^{\circ} \mathrm{C}$ under argon atmosphere. After cooling down to room temperature, single diastereoisomer of 1 (568 $\mathrm{mg}, 0.6 \mathrm{mmol})$, iodobenzene ( $80 \mu \mathrm{L}, 147$ $\mathrm{mg}, 0.72 \mathrm{mmol})$ and $\mathrm{Et}_{3} \mathrm{~N}(100 \mu \mathrm{L}, 73 \mathrm{mg}, 0.72 \mathrm{mmol})$ was added and resulting mixture was refluxed for $3 \mathrm{~h}$, under argon atmosphere. After cooling to room temperature, the solvent was evaporated and the product purified by silica gel chromatography $\left(0-10 \% i\right.$ - $\mathrm{PrOH}$ in $\mathrm{CH}_{2} \mathrm{Cl}_{2}$, containing $0.02 \% \mathrm{Et}_{3} \mathrm{~N}$ ).

3-R. $\boldsymbol{R}_{\mathbf{P}}$ Yellow solid, $516 \mathrm{mg}(86 \%) .{ }^{31} \mathrm{P}$ NMR (202 MHz, $\left.\mathrm{CDCl}_{3}\right): \delta 20.4$.

3-S. Yellow solid, $454 \mathrm{mg}(74 \%) .{ }^{31} \mathrm{P}$ NMR (202 $\left.\mathrm{MHz}, \mathrm{CDCl}_{3}\right): \delta 21.6$.

5'-O-(4,4'-Dimethoxytrityl)thymidin-3'-yl 3'-O-tert-butylsilylthymidin-5'-ylphenylphosphonothioates (4- $\boldsymbol{R}_{\mathbf{P}}$ and $\left.4-\boldsymbol{S}_{\mathbf{P}}\right)$. Single diastereoisomer of $2(578 \mathrm{mg}, 0.6 \mathrm{mmol}), \mathrm{Pd}\left(\mathrm{PPh}_{3}\right)_{4}(69 \mathrm{mg}$, $0.06 \mathrm{mmol})$, iodobenzene $(80 \mu \mathrm{L}, 147 \mathrm{mg}, 0.72 \mathrm{mmol})$ and $\mathrm{Et}_{3} \mathrm{~N}(100 \mu \mathrm{L}, 73 \mathrm{mg}, 0.72 \mathrm{mmol})$ were dissolved in THF $(10 \mathrm{~mL})$ and resulting mixture was refluxed for $30 \mathrm{~min}$, under argon atmosphere. After cooling to room temperature, the solvent was evaporated and the product purified by silica gel chromatography $\left(0-10 \% \mathrm{EtOH}\right.$ in $\mathrm{CH}_{2} \mathrm{Cl}_{2}$, containing $\left.0.02 \% \mathrm{Et}_{3} \mathrm{~N}\right)$.

4- $\boldsymbol{R}_{\mathbf{P}}$. Yellow solid, $567 \mathrm{mg}(91 \%) .{ }^{31} \mathrm{P}$ NMR (162 $\left.\mathrm{MHz}, \mathrm{CDCl}_{3}\right): \delta 88.3$.

4-S $\boldsymbol{S}_{\mathbf{P}}$ Y Yellow solid, $493 \mathrm{mg}(79 \%) .{ }^{31} \mathrm{P} \mathrm{NMR}\left(162 \mathrm{MHz}, \mathrm{CDCl}_{3}\right): \delta$ 89.6.

5'-O-(4,4'-Dimethoxytrityl)thymidin-3'-yl thymidin-5'-yl phenylphosphonates (5- $R_{\mathrm{P}}$ and 5$\left.S_{\mathrm{P}}\right)$ and 5'-O-(4,4'-Dimethoxytrityl)thymidin-3'-yl thymidin-5'-yl phenylphosphonothioates $\left(\mathbf{6}-\boldsymbol{R}_{\mathbf{P}}\right.$ and $\left.\mathbf{6}-\boldsymbol{S}_{\mathrm{P}}\right)$. To a solution of separate diastereoisomers of $\mathbf{3}$ or $\mathbf{4}(0.4 \mathrm{mmol})$ in THF $(4 \mathrm{~mL})$, $1 \mathrm{M}$ TBAF solution $(1 \mathrm{~mL})$ in the same solvent was added. After $20 \mathrm{~min}$ the reaction mixture was concentrated and partitioned between $10 \%$ aq. $\mathrm{NaHCO}_{3}$ and $\mathrm{CH}_{2} \mathrm{Cl}_{2}$. The organic layer was dried over $\mathrm{Na}_{2} \mathrm{SO}_{4}$ and evaporated. The residue was purified by silica gel chromatography $(0-$ $10 \% i$ - $\mathrm{PrOH}$ in $\mathrm{CH}_{2} \mathrm{Cl}_{2}$, containing $0.02 \% \mathrm{Et}_{3} \mathrm{~N}$ ).

5- $\boldsymbol{R}_{\mathbf{P}}$. White solid, $323 \mathrm{mg}(89 \%)$. ${ }^{1} \mathrm{H}$ NMR (500 MHz, $\left.\mathrm{CDCl}_{3}\right): \delta 9.50$ and $9.04\left(2 \mathrm{H}, 2 \times_{\mathrm{s}}, \mathrm{H} 3_{\mathrm{a}}\right.$, $\left.\mathrm{H} 3_{\mathrm{b}}\right), 7.73\left(2 \mathrm{H}, \mathrm{dd}, \mathrm{H} 2_{\mathrm{Ph}}, \mathrm{H} 6_{\mathrm{Ph}}, J_{2 \mathrm{Ph}, 6 \mathrm{Ph}-\mathrm{P}}=13.6 \mathrm{~Hz}, J_{2 \mathrm{Ph}, 6 \mathrm{Ph}-3 \mathrm{Ph}, 5 \mathrm{Ph}}=8.2 \mathrm{~Hz}\right), 7.58\left(1 \mathrm{H}, \mathrm{t}, \mathrm{H} 4_{\mathrm{Ph}}\right.$, $\left.J_{4 \mathrm{Ph}-3 \mathrm{Ph}, 5 \mathrm{Ph}}=7.2 \mathrm{~Hz}\right), 7.52\left(1 \mathrm{H}, \mathrm{s}, \mathrm{H} 6_{\mathrm{a}}\right), 7.44\left(2 \mathrm{H}, \mathrm{m}, \mathrm{H} 3_{\mathrm{Ph}}, \mathrm{H} 5_{\mathrm{Ph}}\right), 7.31-7.13\left(10 \mathrm{H}, \mathrm{m}, \mathrm{H} 6_{\mathrm{b}}, 9\right.$

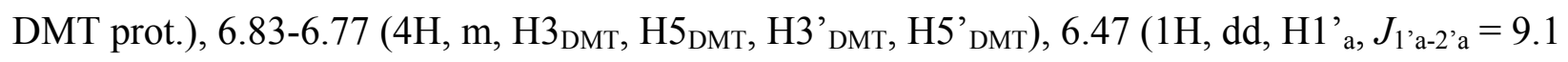

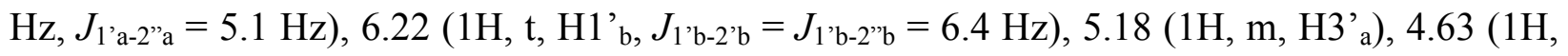
m, H3 ' $\left.{ }_{\mathrm{b}}\right), 4.43-4.28$ (2H, m, H5' $\left.{ }_{\mathrm{b}}, \mathrm{H} 5{ }^{\prime}{ }_{\mathrm{b}}\right), 4.14\left(1 \mathrm{H}, \mathrm{m}, \mathrm{H} 4{ }_{\mathrm{b}}{ }^{2}\right), 4.10$ (1H, m, H4 $\left.{ }_{\mathrm{a}}\right), 3.91$ (6H, s,

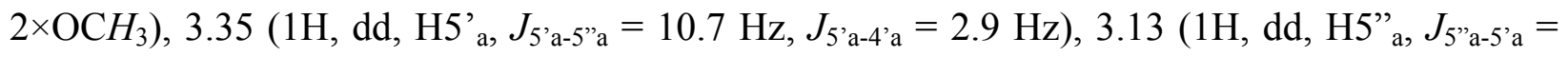
$10.7 \mathrm{~Hz}, J_{5}$ "a-4'a $\left.=2.4 \mathrm{~Hz}\right), 3.08(1 \mathrm{H}, \mathrm{b}, \mathrm{OH}), 2.81\left(1 \mathrm{H}, \mathrm{dd}, \mathrm{H} 2{ }^{\prime}{ }_{\mathrm{a}}, J_{2}\right.$ "a-2'a $=13.6 \mathrm{~Hz}, J_{2}$ "a-1'a $=5.1$ $\mathrm{Hz}), 2.49-2.39\left(2 \mathrm{H}, \mathrm{m}, \mathrm{H} 2{ }^{\prime}{ }_{\mathrm{a}}, \mathrm{H} 2{ }^{\prime}{ }_{\mathrm{b}}\right), 2.22\left(1 \mathrm{H}, \mathrm{m}, \mathrm{H} 2{ }^{\prime}{ }_{\mathrm{b}}\right), 1.70$ and $1.43\left(6 \mathrm{H}, 2 \times \mathrm{s}, 2 \times \mathrm{CH}_{3}\right) .{ }^{13} \mathrm{C}$ NMR (125 MHz, $\left.\mathrm{CDCl}_{3}\right): \delta 164.1$ and $163.9\left(\mathrm{C}_{\mathrm{a}}, \mathrm{C}_{\mathrm{b}}\right), 158.69$ and $158.67\left(\mathrm{C}_{\mathrm{DMT}}, \mathrm{C} 4{ }^{\prime}{ }_{\mathrm{DMT}}\right)$, 151.6 and $151.1\left(\mathrm{C} 2_{\mathrm{a}}, \mathrm{C} 2_{\mathrm{b}}\right), 144.0$ (C1" $\left.{ }_{\mathrm{DMT}}\right), 135.6$ and $134.93\left(\mathrm{C6}_{\mathrm{a}}, \mathrm{C} 6_{\mathrm{b}}\right), 134.95\left(\mathrm{C}_{\mathrm{DMT}}\right.$, C1 ' $\left.{ }_{\text {DMT }}\right), 133.3\left(\mathrm{C}_{\mathrm{Ph}}\right), 131.5\left(\mathrm{~d}, \mathrm{C} 2_{\mathrm{Ph}}, \mathrm{C} 6_{\mathrm{Ph}}, J_{2 \mathrm{Ph}, 6 \mathrm{Ph}-\mathrm{P}}=10.3 \mathrm{~Hz}\right), 129.97$ and $129.94\left(\mathrm{C} 2_{\mathrm{DMT}}\right.$, C6 ${ }_{\mathrm{DMT}}, \mathrm{C} 2{ }^{\text {DMT }}$, C6' ${ }_{\mathrm{DMT}}$ ), 128.9 (d, C3 ${ }_{\mathrm{Ph}}, \mathrm{C} 5_{\mathrm{Ph}}, J_{3 \mathrm{Ph}, 5 \mathrm{Ph}-\mathrm{P}}=16.2 \mathrm{~Hz}$ ), 128.0 (C2" ${ }_{\mathrm{DMT}}, \mathrm{C} 3{ }^{\circ}$ DMT, C5" ${ }_{\text {DMT }}$, C6" ${ }_{\text {DMT }}$ ), 127.2 (C4" $\left.{ }_{\text {DMT }}\right), 126.7$ (d, C1 $\left.1_{\text {Ph }}, J_{1 \mathrm{Ph}-\mathrm{P}}=190.0 \mathrm{~Hz}\right), 113.3$ (C3 ${ }_{\mathrm{DMT}}, \mathrm{C} 5_{\mathrm{DMT}}$,

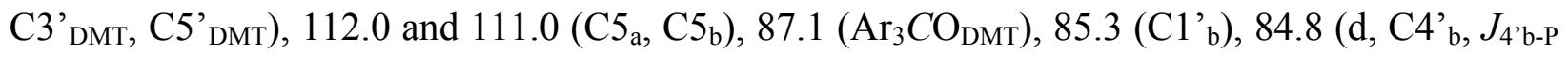


$=6.8 \mathrm{~Hz}), 84.38\left(\mathrm{~d}, \mathrm{C} 4{ }_{\mathrm{a}}{ }_{\mathrm{a}}, J_{4}{ }^{\prime} \mathrm{a}-\mathrm{P}=5.5 \mathrm{~Hz}\right), 84.36\left(\mathrm{Cl}^{\prime}{ }_{\mathrm{a}}\right), 77.9\left(\mathrm{~d}, \mathrm{C} 3{ }_{\mathrm{a}}{ }_{\mathrm{a}}, J_{3}{ }^{\prime} \mathrm{a}-\mathrm{P}=4.5 \mathrm{~Hz}\right), 71.0\left(\mathrm{C} 3{ }_{\mathrm{b}}\right)$, $65.4\left(\mathrm{~d}, \mathrm{C} 5{ }_{\mathrm{b}}{ }_{\mathrm{b}}, J_{5}{ }_{\mathrm{a}-\mathrm{P}}=5.6 \mathrm{~Hz}\right), 63.2\left(\mathrm{C}^{\prime}{ }_{\mathrm{a}}\right), 55.2\left(2 \times \mathrm{OCH}_{3}\right), 40.2\left(\mathrm{C}^{\prime}{ }_{\mathrm{b}}\right), 39.6\left(\mathrm{C}^{\prime}{ }_{\mathrm{a}}\right), 12.3$ and $11.7\left(\mathrm{CH}_{3}\right.$ a, $\mathrm{CH}_{3}$ b). ${ }^{31} \mathrm{P} \mathrm{NMR}\left(202 \mathrm{MHz}, \mathrm{CDCl}_{3}\right): \delta$ 20.2. HRMS: $m / z 931.2952\left([\mathrm{M}+\mathrm{Na}]^{+}\right.$, $\mathrm{C}_{47} \mathrm{H}_{49} \mathrm{~N}_{4} \mathrm{NaO}_{13} \mathrm{P}^{+}$calcd. 931.2926).

5- $\boldsymbol{S}_{\mathbf{P}}$. Yellowish solid, $331 \mathrm{mg}(91 \%), .{ }^{1} \mathrm{H}$ NMR (500 $\left.\mathrm{MHz}, \mathrm{CDCl}_{3}\right): \delta 8.47$ and $8.37(2 \mathrm{H}, 2 \times \mathrm{s}$, $\left.\mathrm{H} 3_{\mathrm{a}}, \mathrm{H} 3_{\mathrm{b}}\right), 7.80\left(2 \mathrm{H}, \mathrm{dd}, \mathrm{H} 2_{\mathrm{Ph}}, \mathrm{H} 6_{\mathrm{Ph}}, J_{2 \mathrm{Ph}, 6 \mathrm{Ph}-\mathrm{P}}=13.6 \mathrm{~Hz}, J_{2 \mathrm{Ph}, 6 \mathrm{Ph}-3 \mathrm{Ph}, 5 \mathrm{Ph}}=7.1 \mathrm{~Hz}\right), 7.64(1 \mathrm{H}, \mathrm{t}$, $\left.\mathrm{H} 4_{\mathrm{Ph}}, J_{4 \mathrm{Ph}-3 \mathrm{Ph}, 5 \mathrm{Ph}}=6.8 \mathrm{~Hz}\right), 7.56-7.49\left(3 \mathrm{H}, \mathrm{m}, \mathrm{H} 6_{\mathrm{a}}, \mathrm{H} 3_{\mathrm{Ph}}, \mathrm{H} 5_{\mathrm{Ph}}\right), 7.38-7.13(10 \mathrm{H}, \mathrm{m}, 9 \mathrm{DMT}$ prot.), 7.07 (1H, s, H6 $\left.{ }_{\mathrm{a}}\right), 6.87-6.80$ (4H, m, H3 ${ }_{\mathrm{DMT}}, \mathrm{H} 5_{\mathrm{DMT}}$, H3 ' $\left.{ }_{\mathrm{DMT}}, \mathrm{H} 5^{\prime}{ }_{\mathrm{DMT}}\right), 6.40$ (1H, dd, H1' ${ }_{\mathrm{a}}, J_{1}$ 'a-2'a

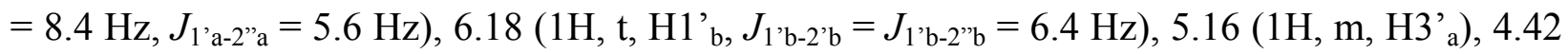
$\left(1 \mathrm{H}, \mathrm{m}, \mathrm{H} 3{ }^{\prime}{ }_{\mathrm{b}}\right), 4.37\left(1 \mathrm{H}, \mathrm{m}, \mathrm{H} 4^{\prime}{ }_{\mathrm{a}}\right), 4.22\left(1 \mathrm{H}, \mathrm{ddd}, \mathrm{H} 5^{\prime}{ }_{\mathrm{b}}, J_{5}{ }^{\prime} \mathrm{b}-5^{\prime} \mathrm{b}=11.8 \mathrm{~Hz}, J_{5}{ }^{\prime} \mathrm{b}-\mathrm{P}=9.6 \mathrm{~Hz}, J_{5}{ }^{\prime} \mathrm{b}-4^{\prime} \mathrm{b}\right.$ $=3.9 \mathrm{~Hz}), 4.13\left(1 \mathrm{H}, \mathrm{ddd}, \mathrm{H} 5{ }^{\prime}\right.$ b, $J_{5}$ ”b-5’b $=11.8 \mathrm{~Hz}, J_{5}$ ”b-P $=8.1 \mathrm{~Hz}, J_{5}$ ”b-4’b $\left.=3.7 \mathrm{~Hz}\right), 3.95(1 \mathrm{H}, \mathrm{q}$,

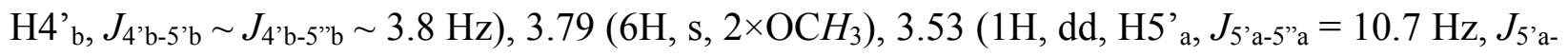
$\left.4{ }^{\prime} \mathrm{a}=2.9 \mathrm{~Hz}\right), 3.41\left(1 \mathrm{H}, \mathrm{dd}, \mathrm{H} 5{ }^{\prime}{ }_{\mathrm{a}}, J_{5}\right.$ "a-5'a $=10.7 \mathrm{~Hz}, J_{5}$ "a-4'a $\left.=2.4 \mathrm{~Hz}\right), 3.18\left(1 \mathrm{H}, \mathrm{d}, \mathrm{OH}, J_{\mathrm{OH}-3{ }^{\prime} \mathrm{b}}=\right.$

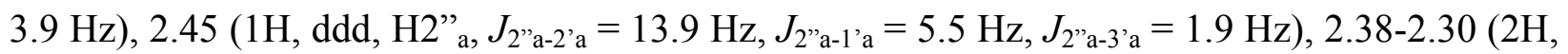
$\mathrm{m}, \mathrm{H} 2{ }^{\prime}{ }_{\mathrm{a}}, \mathrm{H} 2{ }_{\mathrm{b}}$ ), $2.09\left(1 \mathrm{H}, \mathrm{m}, \mathrm{H} 2{ }^{\prime}{ }_{\mathrm{b}}\right), 1.68$ and $1.42\left(6 \mathrm{H}, 2 \times \mathrm{s}, 2 \times \mathrm{CH}_{3}\right) .{ }^{13} \mathrm{C} \mathrm{NMR}(125 \mathrm{MHz}$, $\left.\mathrm{CDCl}_{3}\right): \delta 163.88$ and $163.84\left(\mathrm{C}_{\mathrm{a}}, \mathrm{C}_{\mathrm{b}}\right), 158.72$ and $158.69\left(\mathrm{C}_{\text {DMT }}, \mathrm{C}{ }^{\prime}{ }_{\mathrm{DMT}}\right), 151.6$ and 151.4 $\left(\mathrm{C} 2_{\mathrm{a}}, \mathrm{C} 2_{\mathrm{b}}\right), 144.1$ (C1" $\left.{ }_{\mathrm{DMT}}\right), 135.3$ and $135.2\left(\mathrm{C}_{\mathrm{a}}, \mathrm{C} 6_{\mathrm{b}}\right), 135.06$ and 135.04 (C1 $\left.{ }_{\mathrm{DMT}}, \mathrm{C} 1^{\prime}{ }_{\mathrm{DMT}}\right)$, $133.5\left(\mathrm{C} 4_{\mathrm{Ph}}\right), 131.7\left(\mathrm{~d}, \mathrm{C} 2_{\mathrm{Ph}}, \mathrm{C} 6_{\mathrm{Ph}}, J_{2 \mathrm{Ph}, 6 \mathrm{Ph}-\mathrm{P}}=10.3 \mathrm{~Hz}\right), 130.07$ and $130.04\left(\mathrm{C} 2_{\mathrm{DMT}}, \mathrm{C} 6_{\mathrm{DMT}}\right.$, C2 ' ${ }_{\text {DMT }}, \mathrm{C} 6{ }^{\text {DMT }}$ ), 129.0 (d, C3 $\left.{ }_{\mathrm{Ph}}, \mathrm{C} 5_{\mathrm{Ph}}, J_{3 \mathrm{Ph}, 5 \mathrm{Ph}-\mathrm{P}}=15.3 \mathrm{~Hz}\right), 128.05$ and 128.0 (C2" ${ }_{\text {DMT }}, \mathrm{C} 3{ }^{\circ}$ DMT, C5" ${ }_{\text {DMT }}, \mathrm{C6}{ }^{\text {DMT }}$ ), 127.2 (C4" $\left.{ }_{\text {DMT }}\right), 126.3$ (d, C1 $\left.{ }_{\text {Ph }}, J_{1 \mathrm{Ph}-\mathrm{P}}=189.9 \mathrm{~Hz}\right), 113.3$ (C3 ${ }_{\mathrm{DMT}}, \mathrm{C}_{\mathrm{DMT}}$, C3 ' $\left.{ }_{\text {DMT }}, \mathrm{C} 5{ }^{\prime}{ }_{\text {DMT }}\right), 111.7$ and $111.1\left(\mathrm{C}_{\mathrm{a}}, \mathrm{C} 5 \mathrm{~b}\right), 87.2\left(\mathrm{Ar}_{3} \mathrm{CO}_{\mathrm{DMT}}\right), 84.87\left(\mathrm{Cl}^{\prime}{ }_{\mathrm{b}}\right), 84.80$ (d, C4'

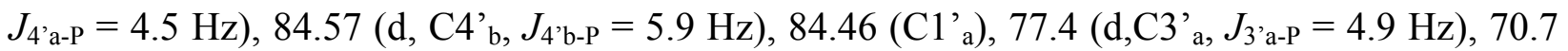
$\left(\mathrm{C} 3{ }^{\prime}{ }_{b}\right), 65.3\left(\mathrm{~d}, \mathrm{C}^{\prime}{ }_{\mathrm{b}}, J_{5}{ }_{\mathrm{a}-\mathrm{P}}=5.5 \mathrm{~Hz}\right), 63.1\left(\mathrm{C}^{\prime}{ }_{\mathrm{a}}{ }^{\prime}\right), 55.2\left(2 \times \mathrm{OCH}_{3}\right), 39.8\left(\mathrm{C} 2{ }^{\prime} \mathrm{b}\right), 38.9\left(\mathrm{~d}, \mathrm{C} 2{ }^{\prime}{ }_{\mathrm{a}}, J_{2}{ }^{\prime} \mathrm{a}-\right.$ $\mathrm{P}=3.6 \mathrm{~Hz}), 12.3$ and $11.7\left(\mathrm{CH}_{3}\right.$ a, $\mathrm{CH}_{3}$ b). ${ }^{31} \mathrm{P} \mathrm{NMR}\left(202 \mathrm{MHz}, \mathrm{CDCl}_{3}\right): \delta 20.8 \mathrm{HRMS}: \mathrm{m} / z$ 931.2913 ([M+Na] $]^{+}, \mathrm{C}_{47} \mathrm{H}_{49} \mathrm{~N}_{4} \mathrm{NaO}_{13} \mathrm{P}^{+}$calcd. 931.2926).

6- $\boldsymbol{R}_{\mathbf{P}}$. Yellow solid, $322 \mathrm{mg}(87 \%)$. ${ }^{1} \mathrm{H} \mathrm{NMR}\left(400 \mathrm{MHz}, \mathrm{CDCl}_{3}\right): \delta 10.41$ and $9.88\left(2 \mathrm{H}, 2 \times_{\mathrm{s}}, \mathrm{H}_{\mathrm{a}}\right.$, $\left.\mathrm{H} 3_{\mathrm{b}}\right), 7.82\left(2 \mathrm{H}, \mathrm{dd}, \mathrm{H} 2_{\mathrm{Ph}}, \mathrm{H} 6_{\mathrm{Ph}}, J_{2 \mathrm{Ph}, 6 \mathrm{Ph}-\mathrm{P}}=14.8 \mathrm{~Hz}, J_{2 \mathrm{Ph}, 6 \mathrm{Ph}-3 \mathrm{Ph}, 5 \mathrm{Ph}}=7.2 \mathrm{~Hz}\right), 7.57\left(1 \mathrm{H}, \mathrm{s}, \mathrm{H} 6_{\mathrm{a}}\right)$, $7.52\left(1 \mathrm{H}, \mathrm{m}, \mathrm{H} 6_{\mathrm{Ph}}\right), 7.42\left(2 \mathrm{H}, \mathrm{m}, \mathrm{H} 3_{\mathrm{Ph}}, \mathrm{H} 5_{\mathrm{Ph}}\right), 7.35-7.20$ (10H, m, H6, $\left.9 H-D M T\right), 6.82$ (4H, d,

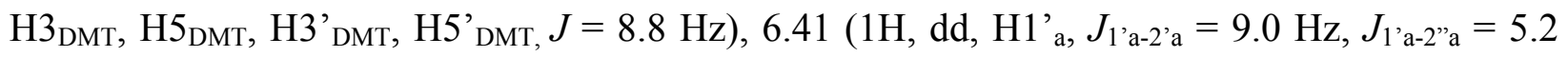

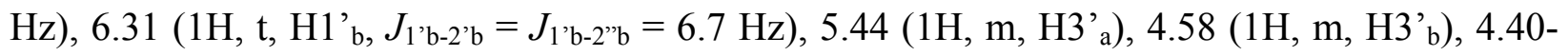
$4.28\left(2 \mathrm{H}, \mathrm{m}, \mathrm{H} 5{ }_{\mathrm{b}}, \mathrm{H} 5{ }^{\prime}{ }_{\mathrm{b}}\right), 4.23\left(1 \mathrm{H}, \mathrm{m}, \mathrm{H} 4{ }_{\mathrm{b}}\right), 4.03\left(1 \mathrm{H}, \mathrm{m}, \mathrm{H} 4{ }_{\mathrm{a}}\right), 3.78\left(6 \mathrm{H}, \mathrm{s}, 2 \times \mathrm{OCH}_{3}\right), 3.31$

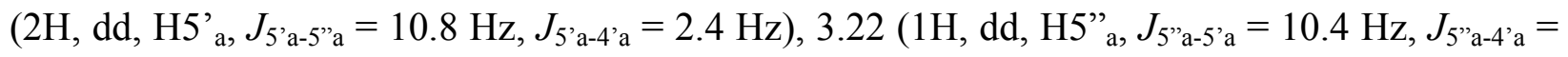

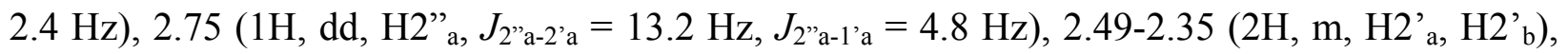
$2.30(1 \mathrm{H}, \mathrm{b}, \mathrm{OH}), 2.08\left(1 \mathrm{H}, \mathrm{m}, \mathrm{H} 2{ }^{\prime}{ }_{\mathrm{b}}\right), 1.60$ and $1.49\left(6 \mathrm{H}, 2 \times \mathrm{s}, 2 \times \mathrm{CH}_{3}\right) .{ }^{13} \mathrm{C} \mathrm{NMR}(100 \mathrm{MHz}$, $\left.\mathrm{CDCl}_{3}\right): \delta 164.3$ and $164.1\left(\mathrm{C}_{\mathrm{a}}, \mathrm{C}_{\mathrm{b}}\right), 158.9$ and $158.8\left(\mathrm{C}_{\mathrm{DMT}}, \mathrm{C} 4{ }^{\prime}{ }_{\mathrm{DMT}}\right), 151.5$ and $150.8\left(\mathrm{C}_{\mathrm{a}}\right.$,

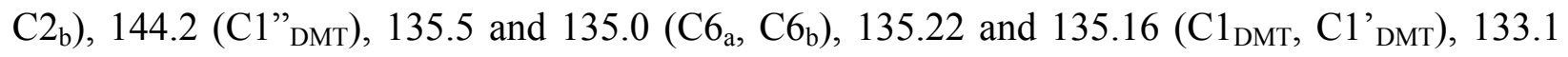
$\left(\mathrm{C} 44_{\mathrm{Ph}}\right), 132.6\left(\mathrm{~d}, \mathrm{C} 1_{\mathrm{Ph}}, J_{1 \mathrm{Ph}-\mathrm{P}}=154.3 \mathrm{~Hz}\right), 130.7\left(\mathrm{~d}, \mathrm{C} 2_{\mathrm{Ph}}, \mathrm{C} 6_{\mathrm{Ph}}, J_{2 \mathrm{Ph}, 6 \mathrm{Ph}-\mathrm{P}}=12.0 \mathrm{~Hz}\right), 130.11$ and 130.08 (C2 $\left.{ }_{\mathrm{DMT}}, \mathrm{C} 6_{\mathrm{DMT}}, \mathrm{C} 2{ }^{\prime}{ }_{\mathrm{DMT}}, \mathrm{C} 6{ }^{\prime}{ }_{\mathrm{DMT}}\right), 128.8$ (d, C3 $\left.{ }_{\mathrm{Ph}}, \mathrm{C} 5_{\mathrm{Ph}}, J_{3 \mathrm{Ph}, 5 \mathrm{Ph}-\mathrm{P}}=15.3 \mathrm{~Hz}\right), 128.2$ and 128.1 (C2" $\left.\mathrm{C}^{\prime}{ }_{\text {DMT }}{ }^{\prime}\right), 112.2$ and $111.2\left(\mathrm{C}_{\mathrm{a}}, \mathrm{C} 5_{\mathrm{b}}\right), 87.4\left(\mathrm{Ar}_{3} \mathrm{CO}_{\mathrm{DMT}}\right), 85.4\left(\mathrm{C} 1^{\prime}{ }_{\mathrm{b}}\right), 85.0\left(\mathrm{~d}, \mathrm{C}^{\prime}{ }_{\mathrm{b}}, J_{4}{ }^{\prime} \mathrm{b}-\mathrm{P}=8.5\right.$ 
$\mathrm{Hz}), 84.9\left(\mathrm{Cl}^{\prime}{ }_{\mathrm{a}}\right), 84.6\left(\mathrm{~d}, \mathrm{C} 4{ }_{\mathrm{a}}, J_{4}{ }^{\prime} \mathrm{a}-\mathrm{P}=6.5 \mathrm{~Hz}\right), 78.9\left(\mathrm{~d}, \mathrm{C} 3{ }_{\mathrm{a}}, J_{3^{\prime} \mathrm{a}-\mathrm{P}}=4.1 \mathrm{~Hz}\right), 71.6\left(\mathrm{C} 3{ }^{\prime}{ }_{\mathrm{b}}\right), 65.8(\mathrm{~b}$, $\left.\mathrm{C} 5^{\prime}{ }_{\mathrm{b}}\right), 63.5\left(\mathrm{C}^{\prime}{ }_{\mathrm{a}}\right), 55.4\left(2 \times \mathrm{OCH}_{3}\right), 40.7\left(\mathrm{C} 2{ }^{\prime}{ }_{\mathrm{b}}\right), 39.9\left(\mathrm{~b}, \mathrm{C} 2{ }_{\mathrm{a}}\right), 12.3$ and $12.0\left(\mathrm{CH}_{3 \mathrm{a}}, \mathrm{CH}_{3 \mathrm{~b}}\right) .{ }^{31} \mathrm{P}$ NMR (162 MHz, $\left.\mathrm{CDCl}_{3}\right): \delta$ 89.2. HRMS: $m / z$ 947.2696 $\left([\mathrm{M}+\mathrm{Na}]^{+}, \mathrm{C}_{47} \mathrm{H}_{49} \mathrm{~N}_{4} \mathrm{NaO}_{12} \mathrm{PS}^{+}\right.$calcd. 947.2698).

6-S. Yellowish solid, $340 \mathrm{mg}(92 \%)$. ${ }^{1} \mathrm{H}$ NMR (400 MHz, $\left.\mathrm{CDCl}_{3}\right): \delta 9.33\left(2 \mathrm{H}, \mathrm{b}, \mathrm{H} 3_{\mathrm{a}}, \mathrm{H} 3_{\mathrm{b}}\right.$ ), $7.89\left(2 \mathrm{H}, \mathrm{dd}, \mathrm{H} 2_{\mathrm{Ph}}, \mathrm{H} 6_{\mathrm{Ph}}, J_{2 \mathrm{Ph}, 6 \mathrm{Ph}-\mathrm{P}}=14.7 \mathrm{~Hz}, J_{2 \mathrm{Ph}, 6 \mathrm{Ph}-3 \mathrm{Ph}, 5 \mathrm{Ph}}=7.1 \mathrm{~Hz}\right), 7.58\left(1 \mathrm{H}, \mathrm{m}, \mathrm{H} 4_{\mathrm{Ph}}\right), 7.55$ (1H, s, H6 $\left.6_{\mathrm{a}}\right), 7.49$ (2H, m, H3 $\left.{ }_{\mathrm{Ph}}, \mathrm{H} 5_{\mathrm{Ph}}\right), 7.41-7.21$ (10H, m, H6, $\left.9 \mathrm{H}-\mathrm{DMT}\right), 7.12$ (1H, m, H6 $6_{\mathrm{a}}$ ), $6.83\left(4 \mathrm{H}, \mathrm{d}, \mathrm{H} 3_{\mathrm{DMT}}, \mathrm{H} 5_{\mathrm{DMT}}, \mathrm{H}{ }^{\prime}{ }_{\mathrm{DMT}}, \mathrm{H} 5{ }^{\prime}{ }_{\mathrm{DMT}} J=8.9 \mathrm{~Hz}\right), 6.41\left(1 \mathrm{H}, \mathrm{dd}, \mathrm{H} 1^{\prime}{ }_{\mathrm{a}}, J_{1}{ }^{\prime} \mathrm{a}-2{ }^{\prime}{ }_{\mathrm{a}}=8.3 \mathrm{~Hz}\right.$,

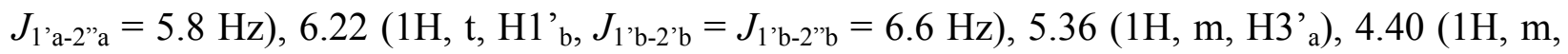
$\left.\mathrm{H} 3{ }^{\prime}{ }_{\mathrm{b}}\right), 4.37\left(1 \mathrm{H}, \mathrm{m}, \mathrm{H} 4{ }^{\prime}{ }_{\mathrm{b}}\right), 4.28-4.04\left(2 \mathrm{H}, \mathrm{m}, \mathrm{H} 5{ }_{\mathrm{b}}, \mathrm{H} 5{ }^{\prime}{ }_{\mathrm{b}}\right), 4.02$ (1H, m, H4 $\left.{ }_{\mathrm{b}}\right), 3.78(6 \mathrm{H}, \mathrm{s}$,

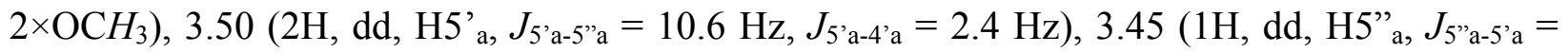
$10.4 \mathrm{~Hz}, J_{5}$ "a-4'a $\left.=2.4 \mathrm{~Hz}\right), 2.42-2.26\left(3 \mathrm{H}, \mathrm{m}, \mathrm{H} 2{ }^{\prime}{ }_{\mathrm{a}}, \mathrm{H} 2{ }^{\prime}{ }_{\mathrm{a}}, \mathrm{H} 2{ }^{\prime}{ }_{\mathrm{b}}\right), 1.96\left(1 \mathrm{H}, \mathrm{m}, \mathrm{H} 2{ }^{\prime}{ }_{\mathrm{b}}\right), 1.85$ (1H, b, $\mathrm{OH}-3{ }^{\prime}$ b), 1.71 and $1.44\left(6 \mathrm{H}, 2 \mathrm{xs}, 2 \mathrm{xCH}_{3}-5\right) .{ }^{13} \mathrm{C} \mathrm{NMR}\left(100 \mathrm{MHz}, \mathrm{CDCl}_{3}\right): \delta 163.9$ and 163.8

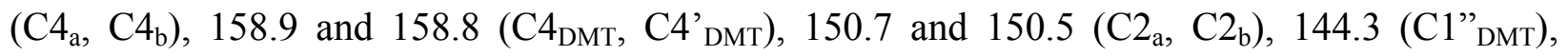
135.25 and 135.22 (C6 $\left.{ }_{\mathrm{a}}, \mathrm{C}_{\mathrm{b}}, \mathrm{C}_{\mathrm{DMT}}, \mathrm{C} 1^{\prime}{ }_{\mathrm{DMT}}\right), 133.4\left(\mathrm{C}_{\mathrm{Ph}}, J_{4 \mathrm{Ph}-\mathrm{P}}=2.8 \mathrm{~Hz}\right), 132.0\left(\mathrm{~d}, \mathrm{C} 1_{\mathrm{Ph}}, J_{1 \mathrm{Ph}-\mathrm{P}}\right.$ $=151.7 \mathrm{~Hz}), 131.1\left(\mathrm{~d}, \mathrm{C} 2_{\mathrm{Ph}}, \mathrm{C} 6_{\mathrm{Ph}}, J_{2 \mathrm{Ph}, 6 \mathrm{Ph}-\mathrm{P}}=12.0 \mathrm{~Hz}\right), 130.25$ and $130.23\left(\mathrm{C} 2_{\mathrm{DMT}}, \mathrm{C} 6_{\mathrm{DMT}}\right.$, C2 ' $\left.{ }_{\text {DMT }}, \mathrm{C} 6{ }^{\prime}{ }_{\text {DMT }}\right), 129.0\left(\mathrm{~d}, \mathrm{C} 3_{\mathrm{Ph}}, \mathrm{C}_{\mathrm{Ph}}, J_{3 \mathrm{Ph}, 5 \mathrm{Ph}-\mathrm{P}}=15.2 \mathrm{~Hz}\right), 128.22$ and 128.18 (C2" ${ }_{\mathrm{DMT}}$,

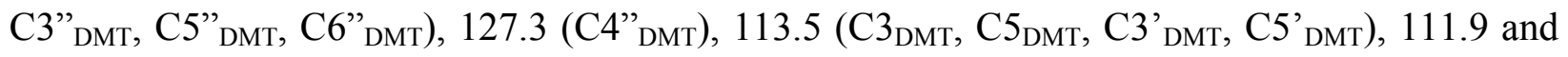
$111.3\left(\mathrm{C}_{\mathrm{a}}, \mathrm{C} 5_{\mathrm{b}}\right), 87.4\left(\mathrm{Ar}_{3} \mathrm{CO}_{\mathrm{DMT}}\right), 85.2\left(\mathrm{~d}, \mathrm{C} 4{ }_{\mathrm{b}}, J_{4}{ }^{\prime} \mathrm{b}-\mathrm{P}=4.0 \mathrm{~Hz}\right), 85.1\left(\mathrm{C}{ }^{\prime}{ }_{\mathrm{b}}\right), 84.8\left(\mathrm{~d}, \mathrm{C}^{\prime}{ }_{\mathrm{a}}, J_{4}{ }^{\prime}{ }_{\mathrm{a}-}\right.$ $\mathrm{P}=8.0 \mathrm{~Hz}), 84.6\left(\mathrm{C} 1{ }_{\mathrm{a}}{ }^{\prime}\right), 78.2\left(\mathrm{~d}, \mathrm{C} 3{ }^{\prime}{ }_{\mathrm{a}}, J_{3}{ }_{\mathrm{a}-\mathrm{P}}=5.0 \mathrm{~Hz}\right), 71.3\left(\mathrm{C} 3{ }_{\mathrm{b}}{ }\right), 65.5\left(\mathrm{~d}, \mathrm{C} 5{ }_{\mathrm{b}}, J_{5}{ }^{\prime} \mathrm{b}-\mathrm{P}=6.0 \mathrm{~Hz}\right)$, $63.2\left(\mathrm{C}^{\prime}{ }_{\mathrm{a}}\right), 55.5\left(2 \times \mathrm{OCH}_{3}\right), 40.2\left(\mathrm{C} 2{ }^{\prime}\right), 39.9\left(\mathrm{~d}, \mathrm{C} 2{ }^{\prime}{ }_{\mathrm{a}}, J_{2}{ }^{\prime} \mathrm{a}-\mathrm{P}=4.9 \mathrm{~Hz}\right), 12.6$ and $11.9\left(\mathrm{CH}_{3}\right.$ a, $\mathrm{CH}_{3}$ b). ${ }^{31} \mathrm{P}$ NMR $\left(162 \mathrm{MHz}, \mathrm{CDCl}_{3}\right): \quad \delta$ 90.9. HRMS: $m / z \quad 947.2697$ ([M+Na] $]^{+}$, $\mathrm{C}_{47} \mathrm{H}_{49} \mathrm{~N}_{4} \mathrm{NaO}_{12} \mathrm{PS}^{+}$calcd. 947.2698).

Phosphoramidite building blocks (7) and (8). 5-(Ethylthio)-tetrazole (0,26 mL, $0.5 \mathrm{M}$ in acetonitrile, Aldrich) was added under argon to a solution of dimer 5 (91 mg, $0.1 \mathrm{mmol}$ ) or 6 (93 $\mathrm{mg}, 0.1 \mathrm{mmol}$ and in freshly distilled methylene chloride $(3 \mathrm{~mL})$. Then 2-cyanoethyl $N, N, N^{\prime}, N^{\prime}-$ tetraisopropyl-phosphordiamidite $(38 \mu \mathrm{L}, 0.11 \mathrm{mmol})$ was added and the reaction mixture was stirred for 15 minutes its progress was monitored by TLC $\left(\mathrm{CHCl}_{3}: \mathrm{MeOH}, 9: 1 \mathrm{v} / \mathrm{v}\right)$. When no further increase in the concentration of product was observed (ca $1 \mathrm{~h}$ ), the reaction mixture was concentrated to half of the initial volume and applied under argon on a silica gel column. The products were eluted with hexane - ethyl acetate $(1: 1, \mathrm{v} / \mathrm{v})$ with triethylamine $(1 \%)$ and with a gradient of methanol (up to 5\%). Fractions containing pure phosphoramidites 7 or 8 were concentrated in vacuo and stored as foams under argon at $-20{ }^{\circ} \mathrm{C}$.

7R. Yield 68\%, Rf (9:1, $\left.\mathrm{CHCl}_{3}: \mathrm{MeOH}\right)$ 0.47; ${ }^{31} \mathrm{P}$ NMR $\left(\mathrm{CDCl}_{3} ; 200 \mathrm{MHz} ; \mathrm{ppm}\right): 148.24$, 149.04, 19.67;

$7 S_{\text {P. }}$ Yield $70 \%$, Rf $\left(9: 1, \mathrm{CHCl}_{3}: \mathrm{MeOH}\right) 0.44 ;{ }^{31} \mathrm{P} \mathrm{NMR}\left(\mathrm{CDCl}_{3} ; 200 \mathrm{MHz} ; \mathrm{ppm}\right): 148.60$, 148.41, 19.42, 19.33;

$8 \boldsymbol{R}_{\mathbf{P}}$. Yield $89 \%$, Rf (9:1, $\left.\mathrm{CHCl}_{3}: \mathrm{MeOH}\right) 0.47 ;{ }^{31} \mathrm{P} \mathrm{NMR}\left(\mathrm{CDCl}_{3} ; 200 \mathrm{MHz} ; \mathrm{ppm}\right): 149.65$, $149.31 ; 88.78 ; 88.62$; 
$8 \boldsymbol{S}_{\mathbf{P}}$. Yield $89 \%$, Rf $\left(9: 1, \mathrm{CHCl}_{3}: \mathrm{MeOH}\right) 0.45 ;{ }^{31} \mathrm{P} \mathrm{NMR}\left(\mathrm{CDCl}_{3} ; 200 \mathrm{MHz} ; \mathrm{ppm}\right): 149.12$, 148.99, 88.72;

Oligonucleotide synthesis. The 3'- $O$-phosphoramidite building units $7 \boldsymbol{R}_{\mathbf{P}}, 7 \boldsymbol{S}_{\mathbf{P}}, 8 \boldsymbol{R}_{\mathbf{P}}$ and $8 \boldsymbol{S}_{\mathbf{P}}$ were used for the synthesis of modified oligomers ODN2-ODN9 by automated solid phase methodology. The $0.2 \mathrm{mmol}$ scale synthesis of oligomers was performed on Gene Word DNA/RNA synthesizer (K\&A, Germany) using succinyl-linked LCA-CPG solid support. The only difference in the manufacturer's recommended protocol was a prolonged coupling time of the modified units (up to $600 \mathrm{~s}$ ). The coupling efficiency of 7 and 8 was determined by DMT-ion assay. The 5'-terminal DMT group was left at the oligonucleotide. The designed oligomers were cleaved from the solid support by treatment with $28 \%$ ammonium hydroxide $(1 \mathrm{~mL})$ for $4 \mathrm{~h}$ at 55 ${ }^{\circ} \mathrm{C}$. The resulting 5'-O-DMT protected oligomers were purified by a standard RP HPLC method. The removal of 5'-DMT group was achieved by treatment with $50 \%$ acetic acid for $30 \mathrm{~min}$ at room temperature, followed by the RP HPLC purification on PRP-1 Hamilton column to produce fully deprotected oligonucleotides ODN2-ODN9 in the yield of 10-19 OD (optical units). The structure and purity of oligomers were confirmed by MALDI-TOF mass spectrometry, 20\% polyacrylamide/ $7 \mathrm{M}$ urea gel electrophoresis (PAGE), and RP HPLC analysis. Reverse phase HPLC was performed on a Gilson apparatus (Middleton, WI, USA) with ThermoQuest Hypersil ODS $5 \mathrm{~m}$ column $(250 \times 4.6 \mathrm{~mm})$ in $0.1 \mathrm{M}$ triethylamine bicarbonate $\mathrm{pH} 7.5$ /acetonitrile buffer system.

\section{CD spectra}

CD spectra of duplexes ODN6 - ODN9 with $\mathrm{dA}_{20}$ and $\mathrm{A}_{20}$ were collected on Jobin Yvon CD6 (France) apparatus. Samples of duplexes $\left(1 \times 10^{-6} \mathrm{M}\right)$ were dissolved in $10 \mathrm{mM}$ Tris-HCl, 100 $\mathrm{mM} \mathrm{NaCl}, 5 \mathrm{mM} \mathrm{MgCl} 2$ buffer $\mathrm{pH} 7.4(1 \mathrm{~mL})$ and the spectra were recorded at 200-320 nm at $25{ }^{\circ} \mathrm{C}$.

\section{Melting temperature measurements}

Samples for the melting temperature measurements (duplexes) were prepared by hybridization of modified oligomers ODN2 - ODN9 with the $\mathrm{dA}_{20}$ and $\mathrm{A}_{20}$ at a concentration $1 \times 10^{-6} \mathrm{M}$ of each oligomer in $10 \mathrm{mM}$ Tris-HCl, $\mathrm{pH} 7.4,100 \mathrm{mM} \mathrm{NaCl}$ and $5 \mathrm{mM} \mathrm{MgCl}$. Melting profiles were recorded after heating to $70{ }^{\circ} \mathrm{C}$ followed by annealing to $5{ }^{\circ} \mathrm{C}$ with a temperature gradient of 1.0 ${ }^{\circ} \mathrm{C} \mathrm{min}^{-1}$. Oligonucleotides were kept for $5 \mathrm{~min}$ at $5{ }^{\circ} \mathrm{C}$ then heated at temperature gradient of 0.2 ${ }^{\circ} \mathrm{C} \min ^{-1}$ to $86{ }^{\circ} \mathrm{C}$. The melting temperatures were calculated using the first order derivative method. Measurements were done on Cintra 40 instrument (GBC Australia).

\section{Assay for digestion of oligonucleotide phenylphosphonates ODN2 and ODN3 and phenylphosphonothioates ODN4 and ODN5}

Assay for digestion of oligo(thymidine phenylphosphonate)s and oligo(thymidine phosphonothioate)s with snake venom phosphodiesterase (PDE I) or calf spleen 
phosphodiesterase (PDE II) was run as follow. Samples of oligonucleotides $\left(0.1 \mathrm{~A}_{260}\right.$ in $10 \mu \mathrm{L}$ of water) were mixed with PDE I ( $1 \mu \mathrm{L}, 0.1 \mathrm{mU})$ or with PDE II $(1 \mu \mathrm{L}, 0.4 \mathrm{mU})$ and incubated at $37{ }^{\circ} \mathrm{C}$. After 1, 20, 60 and $120 \mathrm{~min} 1 \mu \mathrm{L}$ aliquots were withdrawn, mixed with $1 \mu \mathrm{L}$ of the matrix [2,4,6-trihydroxyacetophenone $\left(10 \mathrm{mg} \mathrm{mL}^{-1}\right.$ in water - acetonitrile $\left.1: 1\right)$ - diammonium citrate (50 $\mathrm{mg} \mathrm{mL}^{-1}$ in water), $8: 1, \mathrm{v} / \mathrm{v}$ ] and applied directly to the sample plate. After $10 \mathrm{~min}$ of drying/crystallization the samples were analyzed by MALDI-TOF mass spectrometry using Voyager Elite instrument (PerSeptive Biosystems, USA).

\section{Acknowledgements}

A financial support from the Swedish Research Council and from the Centre of Molecular and Macromolecular Studies of PAS, Poland, is gratefully acknowledged.

\section{References}

1. Miller, P. S. Non-ionic antisense oligonucleotides. In Oligodeoxynucleotides-Antisense Inhibitors of Gene Expression, Cohen, J. S., Ed. Macmillan: New York, 1989; pp 79-95.

2. (a) Cohen, J. S. Trends Biotechnol. 1992, 10, 87. (b) Wozniak, L. A. Rev. Heteroatom Chem. 1999, 19, 173. (c) Lesnikowski, Z. J. Bioorg. Chem. 1993, 21, 127.

3. (a) Shaw, J.-P.; Kent, K.; Bird, J.; Fishback, J.; Froehler, B. Nucleic Acids Res. 1991, 19, 747. (b) Zon, G. Pharm. Res. 1988, 5, 539.

4. (a) Lesnikowski, Z. J.; Przepiorkiewicz, M.; Tamura, Y.; Kaji, H.; Wickstrom, E. Collect. Czech. Chem. Commun. 2001, 66, 912. (b) Vyazovkina, E. V.; Savchenko, E. V.; Lokhov, S. G.; Engels, J. W.; Wickstrom, E.; Lebedev, A. V. Nucleic Acids Res. 1994, 22, 2404. (c) Lesnikowski, Z. J.; Jaworska, M.; Stec, W. J. Nucleic Acids Res. 1990, 18, 2109.

5. Hayakawa, Y.; Hirose, M.; Hayakawa, M.; Noyori, R. J. Org. Chem. 1995, 60, 925.

6. Mag, M.; Muth, J.; Jahn, K.; Peyman, A.; Kretzschmar, G.; Engels, J. W.; Uhlmann, E. Bioorg. Med. Chem. 1997, 5, 2213.

7. Zmudzka, K.; Johansson, T.; Wojcik, M.; Janicka, M.; Nowak, M.; Stawinski, J.; Nawrot, B. New J. Chem. 2003, 27, 1698.

8. Anand, N.; Todd, A. R. J. Chem. Soc. 1951, 1867.

9. Agarwal, K. L.; Riftina, F. Nucleic Acids Res. 1979, 6, 3009.

10. Stawinski, J.; Hozumi, T.; Narang, S. A.; Bahl, C. B.; Wu, R. Nucleic Acids Res. 1977, 4, 353.

11. Hashmi, S. A. N.; Kumar, A.; Katti, S. B. Nucleosides Nucleotides 1994, 13, 1039.

12. Johansson, T.; Stawinski, J. Chem. Commun. 2001, 2564.

13. Hirao, T.; Masunaga, T.; Ohshiro, Y.; Agawa, T. Synthesis 1981, 56.

14. Stawinski, J.; Thelin, M. J. Org. Chem. 1991, 56, 5169. 
15. Lavén, G.; Stawinski, J. Coll. Symp. Series 2005, 7, 195.

16. Stawinski, J.; Strömberg, R.; Zain, R. Tetrahedron Lett. 1992, 33, 3185.

17. Stawinski, J.; Thelin, M. Tetrahedron Lett. 1992, 33, 3189.

18. Xu, Y.; Zhang, J. J. Chem. Soc., Chem. Commun. 1986, 1606.

19. Nielsen, J.; Taagaard, M.; Marugg, J. E.; van Boom, J. H.; Dahl, O. Nucleic Acids Res., 1986, 14, 7391.

20. Caruthers, M. H. Science 1985, 230, 281.

21. Zon, G.; Stec, W. J. In Oligonucleotides and Analogues. A Practical Approach; Eckstein, F. Ed.; IRL Press Oxford University Press, Oxford, 1991; p 87.

22. Jahnson, W. C.; Tinoco, I. Biopolymers 1969, 7, 727.

23. Reynolds, M. A.; Hogrefe, R. I.; Jaeger, J. A.; Schwartz, D. A.; Riley, T. A.; Marvin, W. B.; Daily, W. J.; Vaghefi, M. M.; Beck, T. A.; Knowles, S. K.; Klem R. E.; Arnold Jr., L. J. Nucleic Acids Res. 1996, 24, 4584.

24. Ferguson, D. M.; Kolman, P. A. Antisense Res. Dev. 1991, 1, 234.

25. Chuprina, V. P.; Hienemann, U.; Nurislamov, A. A.; Zielenkiewicz, P.; Dickerson R. E.; Saenger, W. Proc. Natl. Acad. Sci. U.S.A. 1991, 88, 593.

26. Olejniczak, S.; Sobczak, M.; Potrzebowski, M. J.; Polak, M.; Plavec, J.; Nawrot, B. Tetrahedron 2004, 60, 3979.

27. Nawrot, B.; Boczkowska, M.; Wojcik, M.; Sochacki, M.; Kazmierski, S.; Stec, W. J. Nucleic Acids Res. 1998, 26, 2650. 